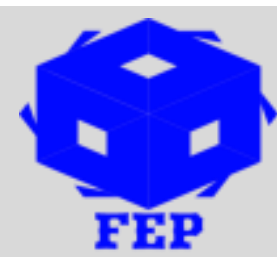

Fair East Publishers

Journal Homepage: www.fepbl.com/index.php/ijarss

\title{
OPTIMIZATION OF THE ROLE OF THE DEPARTMENT OF YOUTH CULTURE AND SPORTS TOURISM OF SUMENEP REGENCY IN THE DEVELOPMENT OF INTEGRATED AND SUSTAINABLE GILI LABAK MARINE TOURISM AREA
}

\author{
Nur Handayani $\mathrm{H}^{1}$., Mas Roro Lilik E²., \& Viv Djanat Prasita ${ }^{3}$ \\ ${ }^{1}$ Master of Public Administration, Faculty of Social and Political Sciences \\ Hang Tuah University, Surabaya, Indonesia \\ ${ }^{2}$ Master of Public Administration, Faculty of Social and Political Sciences \\ Hang Tuah University, Surabaya, Indonesia \\ ${ }^{3}$ Master of Public Administration, Faculty of Social and Political Sciences \\ Hang Tuah University, Surabaya, Indonesia
}

*Corresponding Author: Nur handayani $\mathrm{H}$

Corresponding Author Email: nungshart2@gmail.com

Article Received: 01-11-21 Accepted: 25-11-21

Published: 04-12-21

Licensing Details: Author retains the right of this article. The article is distributed under the terms of the Creative Commons Attribution-Non Commercial 4.0 License (http://www.creativecommons.org/licences/by-nc/4.0/) which permits non-commercial use, reproduction and distribution of the work without further permission provided the original work is attributed as specified on the Journal open access page.

\begin{abstract}
The development of Gili Labak Island by the Tourism, Culture, Youth and Sports Office of Sumenep Regency has started from 2015 to 2020 using the APBD. Initially, the development of Gili Labak Island was initiated by the Sumenep Regency Government. The next trip involved the Kombang Village Government and the people living on the island. This study aims to understand and describe the role of the Department of Tourism, Culture, Youth and Sports of Sumenep Regency in tourism development in the Gili Labak Island Region. By using qualitative research methods, the results of this study state that the role of the Tourism, Culture, Youth and Sports Office of Sumenep Regency in the development of the Gili Labak Maritime Area consists of 3, namely as a motivator, dynamist and facilitator. As a motivator,
\end{abstract}


the Department of Tourism, Culture, Youth and Sports of Sumenep Regency seeks to explore the potential of human resources, nature, and also the awareness of community members in developing the tourism sector in Sumenep Regency. As a facilitator, the Department of Tourism, Culture, Youth and Sports of Sumenep Regency tries to create an orderly, comfortable and safe atmosphere, including facilitating the availability of development facilities and infrastructure such as mentoring and funding. Meanwhile, as the dynamist of the Tourism, Culture, Youth and Sports Office of Sumenep Regency, he provides and trains the community on tourism management on Gili Labak Island, Sumenep Regency. In general, the development of marine tourism areas on Gili Labak Island is good, but tourism facilities and infrastructure in the area need to be improved so that tourism services to visitors are getting better.

Keywords: The Role of the Office, Tourism, Motivator, Dynamizer, Facilitator.

\section{INTRODUCTION}

The tourism sector has become one of the prospective industries and has a multiplier effect (big impact) for development in a region. In its development, tourism involves supporting sectors from the government and the private sector ranging from travel agencies, handicraft/souvenir industries, tourist objects and attractions, hotels, restaurants, and most importantly human resources and available natural resources. Tourism business is an activity that aims to provide tourism services or provide or cultivate tourist objects and attractions, tourism goods businesses and other businesses related to the field. The tourism industry is a set of organizations, both public and private, involved in the development, production and marketing of products and services to meet the needs of people who are traveling. The functions of tourism include increasing business opportunities for residents or communities living around tourist attractions, the tourism sector can absorb labor which can increase income and welfare of the population, increasing state income in the form of taxes both from tourists who come and taxes from social facilities in the area. tourist attraction areas, as well as the benefits of exchanging foreign currency with Indonesian currency for the needs of tourists and the preservation of the environment and national culture. With the existence of tourism, the community always maintains the integrity and sustainability of tourist objects, both natural beauty attractions, historical buildings and relics, as well as the traditional cultures of the community. Unfortunately, this extraordinary potential still feels underdeveloped. (Wibisana, 2013)

When compared to what has been done by countries in Southeast Asia, the growth of the tourism industry in Indonesia still ranks fourth, with tourist visits of 18,281 in 2017 (Ministry of Tourism of the Republic of Indonesia, 2018). This shows that Indonesia is lagging behind in terms of the growth of its tourism industry. This is a problem for the Indonesian state because actually this country has great tourism potential. Therefore, the Central Government and Local Governments must have strategies to increase the number of tourists, both domestic tourists and foreign tourists. To increase tourism potential, an action is needed to develop the tourism area in an integrated and sustainable manner, because tourism areas are an alternative in receiving foreign exchange, expanding job opportunities, and introducing cultural aspects. Indonesia as one of the countries that has very interesting tourist objects, among others, 
namely natural tourism, artificial tourism, historical cultural tourism and marine tourism. Indonesia has seriously paid attention to the development of the tourism sector. The development of the world of tourism is expected to have an impact on increasing tourist visits, this needs to be supported by the availability of public facilities supporting the tourism industry, in addition to continuously improving the objects and tourist attractions that will be offered. This of course requires the role of the Government, Central Government and Local Government in developing tourism potential in Indonesia. (Purwanto, 2016)

The role of the government in developing and managing tourism in general is providing infrastructure (not only in physical form), expanding various forms of facilities, coordinating activities between government officials and the private sector, general regulation and promotion to other regions and abroad. The government has the authority to regulate, provide, and allocate various infrastructures related to tourism needs. The potential of natural wealth if managed or managed properly will provide a large enough role in supporting the achievement of regional development. Many countries in the world have tourism organizations (national tourism boards) funded by the government to promote their tourism activities internationally. According to Wibowo (2007), tourism is the main non-oil and gas commodity which is currently a world trend. Objects that are tourist assets are maintained and treated in a very special way. Of course, because of the special treatment, the tourist attraction is very well preserved. This is a positive aspect of tourism that really pays attention to the interests of preserving the objects that are its assets.

Sumenep or in the Madurese language "Songennep" is one of the districts on the island of Madura, East Java. This district is located at the eastern tip of Madura Island, the geographical condition of the area consists of mainland and islands as many as 126 islands. This area was once part of the large kingdoms centered on the island of Java, such as: Singasari, Majapahit, Demak, and Mataram kingdoms. Sumenep is currently one of the tourist destinations in East Java, especially Madura. Sumenep Regency among all regencies on Madura Island, in Sumenep Regency the tourism sector has experienced a considerable increase with nature tourism being one of its prima donna. The current trending topic is Gili Labak Island. Gili Labak Island has a hidden natural charm in it that is able to attract tourists. The stretch of white sand and blue sea with gentle waves makes Gili Labak Island very worthy of a visit (Marliano, Sarwono, \& Rozikin, 2018).

The white sand of Gili Labak Sumenep is about 50 meters, before Gililabak Island has a very unique attraction, namely the charm of the beauty of marine life which is very diverse, so that it can satisfy snorkeling or diving lovers. In addition, the expanse of clean white sand combined with trees around the beach, the sound of calm waves, the colorful diversity of marine fish and the expanse of coral reefs can make the island's main attraction. The beauty of Gili Labak Island is very worthy to be promoted to foreign countries so that the tourism potential in Indonesia can be seen by other countries. This can be seen in the table below : 
Table 1

Tourist Attraction Visitors in Sumenep Regency in 2017-2019

\begin{tabular}{|c|c|c|c|c|c|c|c|}
\hline \multirow[t]{2}{*}{ Tourism site } & \multicolumn{2}{|c|}{2017} & \multicolumn{2}{|c|}{2018} & \multicolumn{2}{|c|}{2019} & \multirow[t]{2}{*}{ Total } \\
\hline & WA & WI & WA & WI & WA & WI & \\
\hline Gili Iyang & 13 & 3.098 & 14 & 14.359 & 18 & 14.463 & 31.965 \\
\hline Gili Labak & 102 & 12.096 & 121 & 22.941 & 88 & 30.908 & 66.256 \\
\hline Pantai Lombang & 43 & 10.131 & 47 & 19.584 & 59 & 26.840 & 56.704 \\
\hline Pantai Badur & 0 & 2.925 & 0 & 7.639 & 0 & 6.706 & 17.270 \\
\hline Pantai Slopeng & 8 & 3.207 & 10 & 10.943 & 13 & 11.518 & 25.699 \\
\hline Museum dan Keraton & 57 & 9.250 & 85 & 20.271 & 57 & 24.790 & 54.311 \\
\hline Masjid Jami Sumenep & 0 & 11.447 & 0 & 20.764 & 0 & 26.246 & 58.457 \\
\hline Asta Joko Tole & 0 & 2.303 & 0 & 8.941 & 0 & 9.616 & 20.860 \\
\hline Asta Katandur & 0 & 1.111 & 0 & 8.225 & 0 & 5.448 & 14.784 \\
\hline
\end{tabular}

Source: Tourism Office, Sumenep Regency

Description: WA (Foreign Tourists), WI (Indonesian Tourists)

Based on the table above, Gili Labak Island ranks first with the highest number of visitors for three consecutive years from 2017 to the end of 2019. Visitors to Gili Labak Island reached 66,256 people. The existence of Gili Labak Island has begun to be seen in 2017. Gili Labak Island has become a prima donna in Sumenep Regency because many domestic tourists visit this island, even though Gili Labak tourism object is relatively new compared to other tourist destinations in Sumenep Regency. Not a few foreign tourists have also known and visited this island which has a diverse group of coral reefs. Gili Labak is one of the marine tourism destinations in the form of a small island located in Sumenep Regency in Sumenep Regency, Madura. Administratively, this island is located in Lembana Hamlet, Kombang Village, Talango District, Sumenep Regency, East Java or is located in the southeast of Poteran Island or Madura Island. But unfortunately behind the beauty of the island, there are still many supporting facilities for tourism facilities that are lacking to be able to support the tourism potential on Gili Labak Island. This is felt by tourists and managers of marine tourism on the island. One example is the lack of clean water which does not yet have a source of bargaining on the island and electricity that can only be turned on at night, socio-cultural conditions that still seem passive, and the inadequate quality of supporting facilities and infrastructure such as lodging/resorts, mosques/mushola, restaurants, stopovers, souvenir shops, and others. This condition makes the impression that the tourism sector here is still passive and has not received the government's priority to develop this tourism object. However, the tourism potential in the Giri Labak Marine Tourism Area cannot be optimized to continue to increase the Sumenep Regency's Original Regional Income (PAD) and the welfare of the people in Giri Labak. One of the causes is the lack of tourism facilities or infrastructure in the Giri Labak Marine Tourism Area (Marasabessy, Fahrudin, Imran, \& Agus, 2018)

\section{RESEARCH METHOD}

This research is about the role of the Department of Tourism, Culture and Sports of Sampang Regency in developing tourism potential in the Gili Labak Marine Tourism Area using qualitative research methods, namely research methods that describe or describe certain cases or facts or phenomena that occur. This study intends to exploit and clarify a phenomenon or social reality by describing a number of aspects related to the problem under study. The data collected is in the form of words, so it does not emphasize numbers (Sugiyono, 2014). 
Qualitative research methods produce findings that are really useful and require serious attention to various things that are deemed necessary. This type of qualitative research method is a method with data collection on a natural background, which uses natural methods. This research method is used to examine natural subjects, the researcher is the key instrument, data collection techniques are carried out by triangulation (combined), data analysis is inductive and research results require generalization meaning, qualitative research requires accuracy, objective and humble attitude from a researcher (Matthew \& Michael, 2018).

This study focuses on the role of the Tourism, Culture, Youth and Sports Department of Sumenep Regency in developing a marine tourism area on Gili Labak in an integrated and sustainable manner. The role of the Tourism Office will be portrayed from 3 components, namely motivators, facilitators and dynamists. This thesis research takes place in the Gili Labak Island Region, which is in Kombang Village, Talango District, Sumenep Regency, East Java Province. The reason for choosing this location is because Gili Labak Island is a marine tourism destination based on data from the Tourism Office, which is a tourist location in Sumenep Regency that is visited by many tourists, so this study seeks to understand the extent of the role of the Sumenep Regency Youth and Sports Tourism Office in developing the area. coastal tourism. Data collection techniques are the most important step in research, because the main purpose of research is to obtain data. In qualitative research, data collection is carried out in natural conditions (natural setting), primary data sources and data collection techniques are more on participant observation, in-depth interviews and documentation (Sugiyono, 2014).

\section{RESULTS AND DISCUSSION}

Gili Labak Beach Tourism Object offers so many things to do while enjoying the beautiful scenery there. Various beach activities that can be done in this place include:

\section{a. Beach Tour Photography}

This beach is very suitable for doing photography activities, and will amaze everyone when the results are uploaded on social media. In addition to the beautiful surrounding scenery, the stretch of white sand and clear blue water on this beach can be a perfect refreshing backdrop for the audience.

\section{b. Snorkeling / Underwater Diving}

Not only on land, the underwater conditions around this beach have a beautiful charm and also have very clear bluish water. If you have a hobby of snorkeling or diving, then this activity is highly recommended to do. There are dive equipment rentals available and the fishermen are usually happy to ride you to the desired dive spot (Manafi, 2019)

The Department of Tourism, Culture, Youth and Sports (Disparbudpora) of Sumenep Regency has the main task of assisting the Regent in carrying out the formulation and implementation of policies in the fields of tourism development, culture, youth and sports (www.sumenepkab.go.id) The Disparbudpora of Sumenep Regency has functions, as the following (a) formulation of technical policies, preparation and coordination of work programs for the implementation of tasks in tourism, culture, youth and sports fields; (b) Policy planning and implementation of tourism, cultural, youth and sports activities; (c) Implementation of regional government affairs and public services in the fields of culture, tourism, youth, sports; (d) Guidance and implementation of tasks in the field of tourism, culture, youth, sports (e) Administration of secretarial administration; (f) Carrying out other tasks assigned by the 
Regent in accordance with his duties and functions. The following is the role of the Tourism, Culture, Youth and Sports Office of Sumenep Regency as a motivator, facilitator and dynamist in the development of marine tourism in the Gili Labak area, Sumenep Regency (Mukhlish, 2014)

\section{Motivator}

The motivator in tourism management, the role of the Sumenep Regency Government as a motivator that encourages people to move to manage and develop the potential of Gili Labak Island, as a potential Sumenep tourist attraction. Motivation is necessary because the community must be encouraged to better understand where the development and management of these natural attractions are headed. necessary for the tourism business to continue. Investors, the community, and entrepreneurs in the tourism sector are the main targets that need to be continuously motivated so that tourism development can run well. Based on the research, it can be concluded that there is still a lack of public awareness to manage and develop the existing potential of Gili Labak Island. There needs to be encouragement and motivation from the government so that people are aware that tourism development can run well. The Department of Tourism, Culture, Youth and Sports of Sumenep Regency as a motivator for managing tourism is one of the work programs carried out by the promotion and product marketing section in the field of tourism development and management to improve the quality of service for the government and the community towards Gili Labak Island tourists. What the Tourism Office does in tourism management is because in the tourism sector it offers pleasant and satisfying services for tourists, so that tourists feel like returning to travel to these tourist destinations. The Department of Tourism, Culture, Youth and Sports of Sumenep Regency manages all tourist attractions on Gili Labak Island in stages, because as the role of the Tourism Office in managing tourism to provide a positive image for tourists who come to Gili Labak Island. The Tourism Office manages tourism so that its performance produces good results for the assessment of the central government, so that it is assessed that the Sumenep Regency Tourism, Culture, Youth and Sports Office has carried out its role with good results. The Tourism Office plays an important role as stated in the Vision of the Tourism and Culture Office of Sumenep Regency "Excellent Tourism in Sumenep Regency Based on Marine Tourism and Ecotourism with Competitive and Global Insight in 2025". (Octafianus, 2017) The community is a tourism management actor who has a very central role, because the community is also the host in general in direct contact with tourists visiting Gili Labak Island such as providing services and maintaining order and comfort in the tourist area. The Sumenep Regency Tourism Office will not stand alone in managing tourism on Gili Labak Island, without the cooperation of the existing power holders, namely the community and the government. The Tourism Office has tried to manage tourism well. The Department of Tourism, Culture, Youth and Sports of Sumenep Regency is one of the agencies located in Sumenep Regency with the role it bears as the organizer of regional government affairs, especially in the tourism and culture sector of Sumenep Regency. In accordance with its duties and functions, the Department of Culture and Tourism of Sumenep Regency has a very large role, especially in the development of tourism and the preservation of culture in Sumenep Regency. The Tourism Office is obliged to manage tourism, by managing regional cultural arts assets, traditional values, historical and archaeological sites. The Tourism Office introduces the potential of the area / object and tourist attraction of Gili Labak Island outside 
the region both domestically and abroad with the strategy it does, as a motivator it must manage tourism. Increasing the attractiveness of tourism objects or tourism management that is able to move other sectors including the preservation of natural resources and the people's economy around tourist areas.

\section{Facilitator}

A facilitator is someone who on behalf of the government or management agency is obliged to influence the decision-making process carried out by potential beneficiaries in dealing with innovation. The role of the government as a facilitator is to create conditions conducive to the implementation of development or to bridge the interests of various parties in optimizing regional development. As a facilitator, the government tries to create an orderly, comfortable and safe atmosphere, including facilitating the availability of development facilities and infrastructure such as assistance and funding. The government acts as a facilitator who provides or provides facilities in this case the Tourism, Culture, Youth and Sports Office of Sumenep Regency as the manager of tourism objects. The Department of Tourism, Culture, Youth and Sports of Sumenep Regency continues its second role, namely as a facilitator. In this context, the Sumenep tourism office provides guidance to the community on the use of techniques, strategies, and implementation in programs that are beneficial to the development of the potential of Gili Labak Island.

a. Provide facilities and infrastructure

Providing tools and buildings that make visitors feel at home on the island by providing prayer rooms, toilets, villas, gazebos and various other facilities.

b. Facilitating Community Activities

Meeting the needs that visitors want to come back to the island, such as providing bathrooms, clean water and electricity. The government acts as a facilitator who provides or provides facilities in this case the Tourism Office as a tourist attraction manager. The Tourism Office continues its second role, namely as a facilitator. In this context, the Sumenep tourism office provides guidance to the community on the use of techniques, strategies, and implementation in programs that are beneficial to the development of the potential of Gili Labak Island.

Based on the author's observations in the field of Gili Labak Island tourism, they still need facilities that can support the development of Gili Labak Island attractions, for example, increasing clean water and electricity because the main resting place for visitors is still inadequate. The facilities and infrastructure in the tourism sector that have been provided by the government are diving equipment, banana boats, snorkeling, waterparks, villas, meeting rooms, and prayer rooms. The facilitator for the Tourism, Culture, Youth and Sports of Sumenep Regency was an official effort from the beginning, of course it was in facilitating the community from every point of view to be able to manage in their respective regions by raising what potential exists by forming an organization or team under the supervision of the Tourism Office, the point is to the community around Gili Labak Island is aware of tourism, and can live in prosperity with extraordinary tourism potential, on Gili Labak Island. So the community also plays a role in the management of Gili Labak Island tourism. In carrying out its role in tourism and culture, the Department of Tourism, Culture, Youth and Sports of Sumenep Regency facilitates tourists who want to get information about tourism on Gili Labak Island through tour guide facilities. In terms of tourism management on Gili Labak Island, the 
efforts made by the Department of Tourism, Culture, Youth and Sports, Sumenep Regency seek to facilitate the community to realize community-based tourism and facilitate various kinds of community and tourist needs in supporting tourism activities. Meanwhile, in carrying out its role as a facilitator, the Department of Tourism, Culture, Youth and Sports of Sumenep Regency cooperates with the community. The people who cooperate with the Tourism Office are boat owners and restaurant owners. The aspirations of the community become meaningful input for the Tourism, Culture, Youth and Sports Office of Sumenep Regency as an input that can be used as policy considerations in an effort to fix Gili Labak Island. On the other hand, the actions of the tourism office also provide benefits for the local community in preserving existing tourist attractions and cultural wealth.

\section{Dynamist}

The government's role as a dynamist is to mobilize community participation if there are obstacles in the development process to encourage and maintain the dynamics of regional development. The government plays a role by providing intensive and effective guidance and direction to the community. Usually the provision of guidance is realized through a team of extension workers or certain agencies to provide training. The role of the Department of Tourism, Culture, Youth and Sports of Sumenep Regency as a dynamist, namely:

a). Providing Guidance and Guidance

Provide hints or guidelines to local communities around the island to use kappa and their expertise to generate income from visitors.

b). Providing Training

Activities that direct the community around Gili Labak Island to hone their skills in making souvenirs or souvenirs typical of the island to be traded to visitors. So that the three roles of the Culture and Tourism Office of Sumenep Regency are mutually sustainable in increasing the number of visitors to Gili Labak Island tourism objects.

The Tourism, Culture, Youth and Sports Office of Sumenep Regency carries out tourism development with the community in the management of Gili Labak Island tourism, because it has been confirmed that the Department cannot run alone and work alone to manage Gili Labak Island tourism without the intervention of existing power holders, namely the government and the community. . Tourism activities are systemic and their implementation cannot be carried out separately, so like it or not, there must be synergy between existing stakeholders. The Department of Tourism, Culture, Youth and Sports of Sumenep Regency in order to carry out the role of a dynamist is to monitor tourism, especially the community. In addition to monitoring tourism service businesses on Gili Labak Island, the Tourism Office also carries out a destination mix business or approach, a Strategic Management Approach, an Integrated Planning Approach and a sustainable tourism development approach for community empowerment around Gili Labak Island. Because there are many people who have businesses on Gili Labak Island. So that with the efforts of the Sumenep Regency Youth and Sports Culture Tourism Office in approaching the community, it will provide many benefits for community-based tourism development. As an effort of the Tourism, Culture, Youth and Sports Office of Sumenep Regency in carrying out its role as a dynamist, so far it has done various things related to cooperation between sectors, both other government parties and the community. Government and community parties in tourism development play an important role, which helps the development of Gili Labak Island tourism. The Department of Tourism, 
Culture, Youth and Sports of Sumenep Regency carries out tourism development with the community in the development of tourism. So that people with addresses in tourist areas are obliged to promote tourism in their area and be enlivened by the presence of foreign parties. The Tourism Office carries out tourism development with the principles and guidelines used based on the people. That is the extent to which the development of the tourism sector can provide great benefits to the community that supports community participation in tourism development.

\section{CONCLUSION}

Based on the results of research and discussions conducted regarding the development of the Gili Labak Island Marine Tourism Area, Sumenep Regency, they are as follows:

The development of Gili Labak Island by the Tourism, Culture, Youth and Sports Office of Sumenep Regency has started from 2015 to 2020 using the APBD. Initially, the development of Gili Labak Island was initiated by the Sumenep Regency Government. The next trip involved the Kombang Village Government and the people living on the island. The role of the Tourism, Culture, Youth and Sports Office of Sumenep Regency in the development of the Gili Labak Maritime Area consists of 3, namely as a motivator, dynamist and facilitator. As a motivator, the Department of Tourism, Culture, Youth and Sports of Sumenep Regency seeks to explore the potential of human resources, nature, and also the awareness of community members in developing the tourism sector in Sumenep Regency. As a facilitator, the Department of Tourism, Culture, Youth and Sports of Sumenep Regency tries to create an orderly, comfortable and safe atmosphere, including facilitating the availability of development facilities and infrastructure such as mentoring and funding. Meanwhile, as the dynamist of the Tourism, Culture, Youth and Sports Office of Sumenep Regency, he provides and trains the community on tourism management on Gili Labak Island, Sumenep Regency. In general, the development of marine tourism areas on Gili Labak Island is good, but tourism facilities and infrastructure in the area need to be improved.

\section{References}

Manafi, M.R. (2019). Application of the Carrying Capacity Concept for Sustainable Development in Small Islands (Case Study of the Kaledupa Island Cluster, Wakatobi Regency). Journal of Indonesian Aquatic and Fishery Sciences, 16(1).

Marasabessy, I., Fahrudin, A., Imran, Z., \& Agus, S.B. (2018). Coastal and Marine Sustainable Management Strategy on Nusa Manu Island and Nusa Leun Island in Central Maluku Regency. Journal of Regional and Development Planning, 2(1).

Marliano, D., Sarwono, Rozikin, M. (2018). Coastal Area Management Policy in Sampang Regency (Study at Bappeda of Sampang Regency). Journal of Public Administration (JAP), 1(3), 80-86.

Matthew, M., \& Michael, H. (2018). Qualitative Data Analysis: A Resource Book on New Methods. University of Indonesia, Jakarta.

Mukhlish, (2014). The Concept of Environmental Administration Law in Realizing Sustainable Development. Journal of the Constitution, 7(2),

Octafianus, O. (2017). The Effectiveness of the Use of Vehicle Parking Land at the Lasiana Beach Tourism Object Kupang which has an impact on increasing the income of the 
community and the local government of the Kupang Municipality. Journal of Civil Engineering 2(1).

Purwanto, H. (2016). Efforts to Increase Blitar City's Local Revenue Through the Implementation of Blitar City Regulation Number 4 Year 2004 (Thesis), Public Administration I1mu Study Program, Universitas Brawijaya Malang.

Rigg, K. in L Tri Setyawanta, (2015). Basic Concepts and Problems of Integrated Coastal Management in a National Scope, PSHL FH UNDIP, Semarang.

Sedarmayanti (2014). Building \& Developing Culture \& Tourism Industry (Anthology of Tourism Writing) Bandung: Refika Aditama.

Sudanti (2012). Evaluation of Environmental Carrying Capacity in Genuk Industrial Area, Semarang. Proceedings of the National Seminar on Environment and Natural Resource Management in Semarang.

Susilo, K. (2000). Regional Development in Coastal Areas, Papers in the National Seminar on Regional Development and Management of Natural Resources in Coastal Areas in the Context of Sustainable Regional Spatial Planning, FH UNPAD, Bandung, 13 May 2000.

Syrup, R. (2014). The Role of the Government in the Management of Tourism Potential in North Toraja Regency. North Toraja. Hasanuddin University

Wibisana, A.G. (2013). Sustainable Development: Legal Status and Its Meaning. Journal of Law and Development, 1 . 